\title{
A new method for the conservation of ancient colored paintings on ramie textiles
}

\author{
Jiaojiao Liu*, Yuhu Li*, Daodao Hu, Huiping Xing, Xiaolian Chao, Jing Cao and Zhihui Jia
}

\begin{abstract}
Textiles are valuable cultural heritage items that are susceptible to several degradation processes due to their sensitive nature, such as the case of ancient ma colored-paintings. Therefore, it is important to take measures to protect the precious ma artifacts. Generally, "ma" includes ramie, hemp, flax, oil flax, kenaf, jute, and so on. In this paper, an examination and analysis of a painted ma textile were the first step in proposing an appropriate conservation treatment. Standard fiber and light microscopy were used to identify the fiber type of the painted ma textile. Moreover, custom-made reinforcement materials and technology were introduced with the principles of compatibility, durability and reversibility. The properties of tensile strength, aging resistance and color alteration of the new material to be added were studied before and after dry heat aging, wet heat aging and UV light aging. After systematic examination and evaluation of the painted ma textile and reinforcement materials, the optimal conservation treatment was established, and exhibition method was established. Our work presents a new method for the conservation of ancient Chinese painted ramie textiles that would promote the protection of these valuable artifacts.
\end{abstract}

Keywords: Painted textiles, Ramie fiber, Conservation methods, Reinforcement, Cultural relic

\section{Introduction}

Textiles in all forms are an essential part of human civilization [1]. The raw materials that have been used for textiles include cotton, ma, silk, wool, goat hair, and so on. Previous reports mainly focus on the degradation and ageing of linen, wool and silk textiles [2-5], the preservation environment of archaeological textiles $[6,7]$, the analysis and identification of textile components [8-13], the fungal contamination and splicing technology of textile objects $[14,15]$. After the first conference on textile conservation held by IIC in The Netherlands in 1964 [16], certain textile conservation methods have been developed, including disinfecting of textile objects [17], cleaning [18], mounting [19], and stitching techniques [20].

It is well known that ma textiles have been used for making uniforms, ropes, paintings, and scriptures.

*Correspondence: liujiaojiao@snnu.edu.cn; liyuhu@snnu.edu.cn Engineering Research Center of Historical Cultural Heritage Conservation, Ministry of Education, School of Materials Science and Engineering, Shaanxi Normal University, Xi'an 710119, China
Among them, painted ma textiles are characterized by the flexibility, draping quality, heterogeneity, and multiple layers, making them complex objects to conserve. Ma textiles are made of ma including ramie, hemp, flax, oil flax, kenaf, jute, and so on [21]. China has a history of more than five thousand years and since the Liao and Jin era are significant periods in ancient China, many macolored paintings from Buddhist culture and history have been preserved (Fig. 1). These works provide an important reference to understand the historical prosperity, decline and nature of Buddhist culture in the Chinese Liao and Jin era. Unfortunately, all textiles, including ma textiles in museums are exposed to many risks such as uncontrolled relative humidity $(\mathrm{RH})$ and temperature, light and air pollution, and non-standard storage and display methods $[22,23]$. The ma fibers are hygroscopic, thus they could react with water, carbon dioxide, and also sulfur dioxide in the air leading to deterioration of the fibers [24]. In addition, the deposition of dust and microorganisms on the surface accelerates chemical reactions that lead to loss of tensile strength and pliability [25]. As
Springer Open

(c) The Author(s) 2021, corrected publication 2021. This article is licensed under a Creative Commons Attribution 4.0 International License, which permits use, sharing, adaptation, distribution and reproduction in any medium or format, as long as you give appropriate credit to the original author(s) and the source, provide a link to the Creative Commons licence, and indicate if changes were made. The images or other third party material in this article are included in the article's Creative Commons licence, unless indicated otherwise in a credit line to the material. If material is not included in the article's Creative Commons licence and your intended use is not permitted by statutory regulation or exceeds the permitted use, you will need to obtain permission directly from the copyright holder. To view a copy of this licence, visit http://creativecommons.org/licenses/by/4.0/. The Creative Commons Public Domain Dedication waiver (http://creativeco mmons.org/publicdomain/zero/1.0/) applies to the data made available in this article, unless otherwise stated in a credit line to the data. 


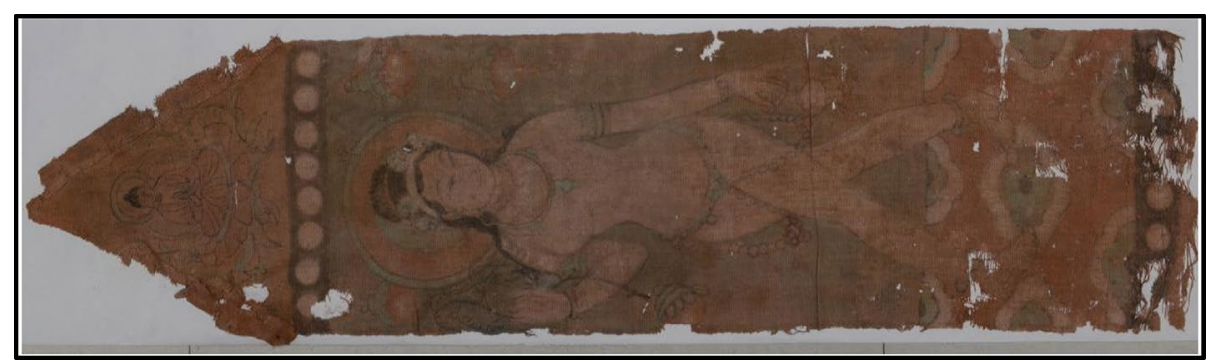

Fig. 1 The painted ma textile object dates to Chinese Liao and Jin era $(160 \times 30 \mathrm{~cm})$

a result, the ornamental value of ma fabric is affected. As far as we know, there are few studies on conservation methods of painted ma textiles. Previously, researchers $[26,27]$ reported some analytical techniques for the identification and characterization of textile materials, the categorization of painted textile, and a collaborative approach between textile and paintings conservators on lining and mounting painted textiles.

Good conservation policy for painted ma textiles should not be only about protection against the risks caused by environmental factors, but also about the use of appropriate conservation methods, required by scientific research. In this article, the selection of reinforcement materials was the first step for these conservation methods. Reinforcement materials should possess an appropriate structure, weight, and fiber to provide adequate support to the ma textiles [28]. Thereby, the type of fibers and extent of damage were studied through different ways of investigation. Before the identification on the fiber type of the original object, painted ma textile was used. After it is completed, painted ramie textile, ramie fiber or ramie net was used. Then, based on the principles of compatibility, durability and reversibility, the new reinforcement materials and techniques were decided. Finally, the conservation methods of the Chinese painted ramie textiles were developed, including realignment of the distorted weave, consolidation of the painting layer, wet cleaning and stain removal, fine realignment of the fibers, reinforcement of the ramie net and in-fill of areas of loss. This work aimed to propose conservation methods for Chinese painted ramie textiles, which would enrich conservation scientist's information about the conditions of conservation and physical chemical properties of reinforcement materials [29].

\section{Experimental}

\section{Historical context}

As shown in Fig. 1, there is a colored ma drawing: a pair of Bodhisattva banner-hangings. The banner hand on the left and right of the banner body and the banner foot below have been lost, and both have height of $160 \mathrm{~cm}$ and width of $30 \mathrm{~cm}$. The body of this pair of banner-hanging Bodhisattvas showed the image of Bodhisattvas in Early Indian Buddhism, and it is a rare Buddha painting made on ramie fiber. The painting shows light and dark expressive methods, and the painting style has characteristics that integrate many artistic features of India, Greece and the Western Regions of China. This pair of the colored ramie drawing Bodhisattva banner-hangings originates from the Western Regions of China during the Northern and Southern Dynasties [30]. As shown in Fig. 2, there were many signs of damage on the object, such as many missing areas and weft yarn.

\section{Characterization of ma fiber in the painted textile}

Based on the compatibility principle of reinforcement materials, this experiment applied one analysis method to identify the fiber type of colored painting of ma textile. Preparation of Herzberg coloring agent and samples has been reported [31, 32]. Light microscopy (LM) was used to observe and compare the fiber morphology of ma fiber from painted textile and standard fiber.

\section{Evaluation of reinforcement material}

The Xi'an Yuanhaohuazang Museum has collected the colored ramie paintings of the Chinese Liao and Jin era, and samples were taken from the fragments of the degraded colored ramie paintings. The reinforcement material was prepared with the ramie net. Polyvinyl alcohol 217 (PVA-217), ramie fiber and water-based fluororesin were purchased from a commercial company and used as received.

\section{Accelerated aging of reinforcement material}

Three general aging methods were employed for the accelerated aging of the reinforcement material, and three parallel experiments were carried out for each group of aging methods. Each sample was aged for 3, 5, and 7 days. Heating textiles or paper for $72 \mathrm{~h}$ (3 days) at $100{ }^{\circ} \mathrm{C}$ is equivalent of approximately 25 years of natural 


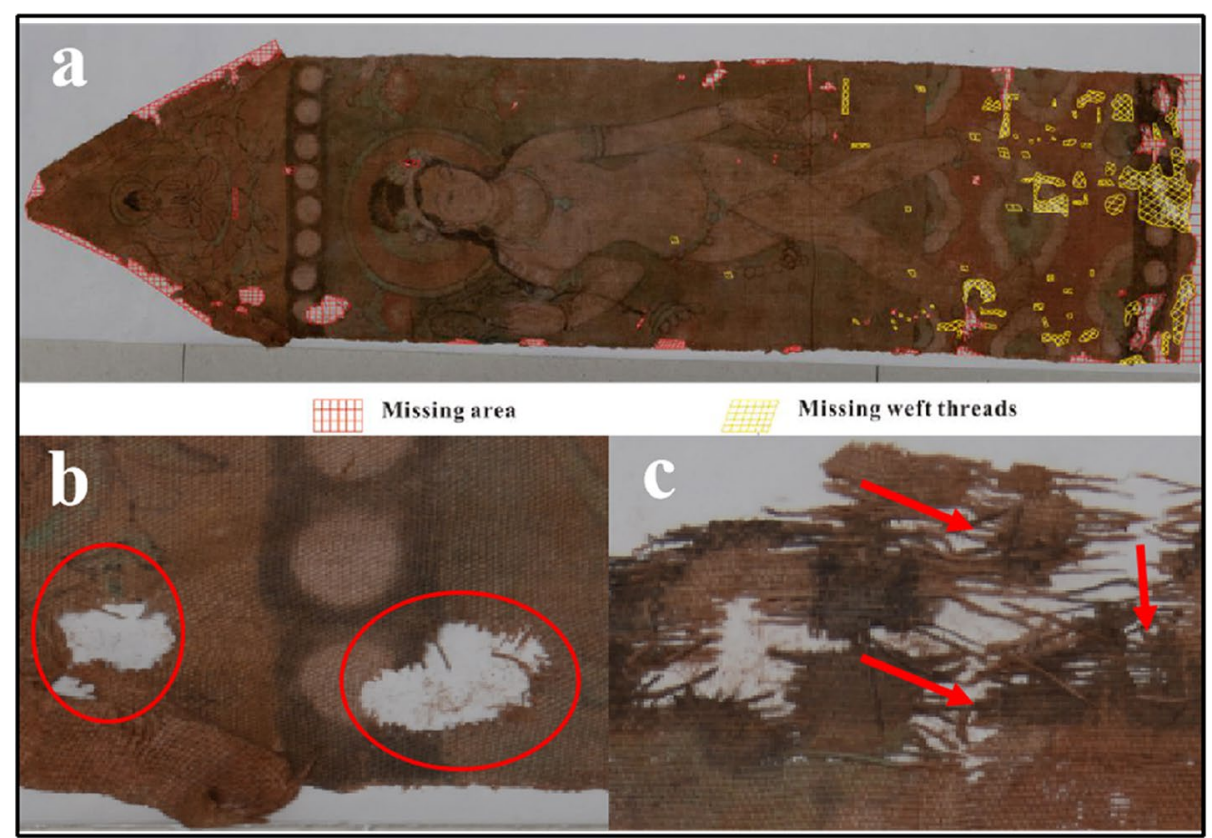

Fig. 2 The types of damage of the ma textile colored painting (a): There are mainly two signs of damage on this object: missing areas (b); missing weft yarn (c)

aging under normal condition [16]. One aging method was dry heat aging, the prepared ramie net and PVA film were put in a blast drying aging box at $105^{\circ} \mathrm{C}$. The second method was wet heat aging, the prepared ramie net and PVA film were put in a constant damp heat aging test box at a temperature of $80{ }^{\circ} \mathrm{C}$ and a relative humidity of $65 \%$. The third method was ultraviolet light aging, an ultraviolet weather resistant test box was to age the ramie net and PVA film, the temperature of the aging box was set at $25^{\circ} \mathrm{C}$, the power of the ultraviolet lamp was $60 \mathrm{~W}$, and the vertical distance between the sample and the ultraviolet lamp was $5 \mathrm{~cm}$.

\section{Tensile strength of reinforcement material before and after aging}

The QT-1136 universal material testing machine was used to test the tensile strength of the ramie net before and after aging for 5 days. The samples were cut into long strips of about $15 \mathrm{~mm} \times 5 \mathrm{~mm}$, then a universal material testing machine was used to measure the load when the ramie net was broken. Each sample was measured 10 times to get the average value of the load. The tensile strength was calculated according to the formula: $\mathrm{S}=\mathrm{F} /$ $\mathrm{Lw}$, where $\mathrm{F}$ was the load at break, and Lw was the width of the sample. The X-RiteVS-450 spectrophotometer was applied to test the chromatic aberration $\Delta \mathrm{E}^{*}$ of the reinforcement materials before and after aging for 3, 5, and
7 days, and each sample was measured 5 times to get the average value. Four layers of ramie net were superimposed to perform the test. The larger the value of $\Delta E^{*}$, the greater the color change of the sample.

\section{Conservation process}

The Chinese Liao and Jin era dates back more than a thousand years, and as such many colored paintings of ma fabrics have been buried underground for years, and they are damaged, severely affecting their viewing and exhibition in museums. Certain conservation, such as realignment of the distorted weave, consolidation of the painting layer, wet cleaning and stain removal, fine realignment of the fibers, reinforcement of the ramie net and in-fill of areas of loss.

\section{Results and discussion}

\section{Fiber analysis of ma textile sample}

LM was used to identify the fiber type of ma textile sample. As shown in Fig. 3a, b, the morphology of standard ramie fiber is relatively thick (the average width of the fiber is $30-60 \mu \mathrm{m}$ ), one part of the fiber is shaped like a circular tube, and another part of the fiber is shaped like a flat long ribbon. It shows clear longitudinal stripes, obvious horizontal knots on the fiber wall, and a wine-red color [33, 34]. Careful morphology comparison between standard ramie fiber and fiber of painted ma textile 


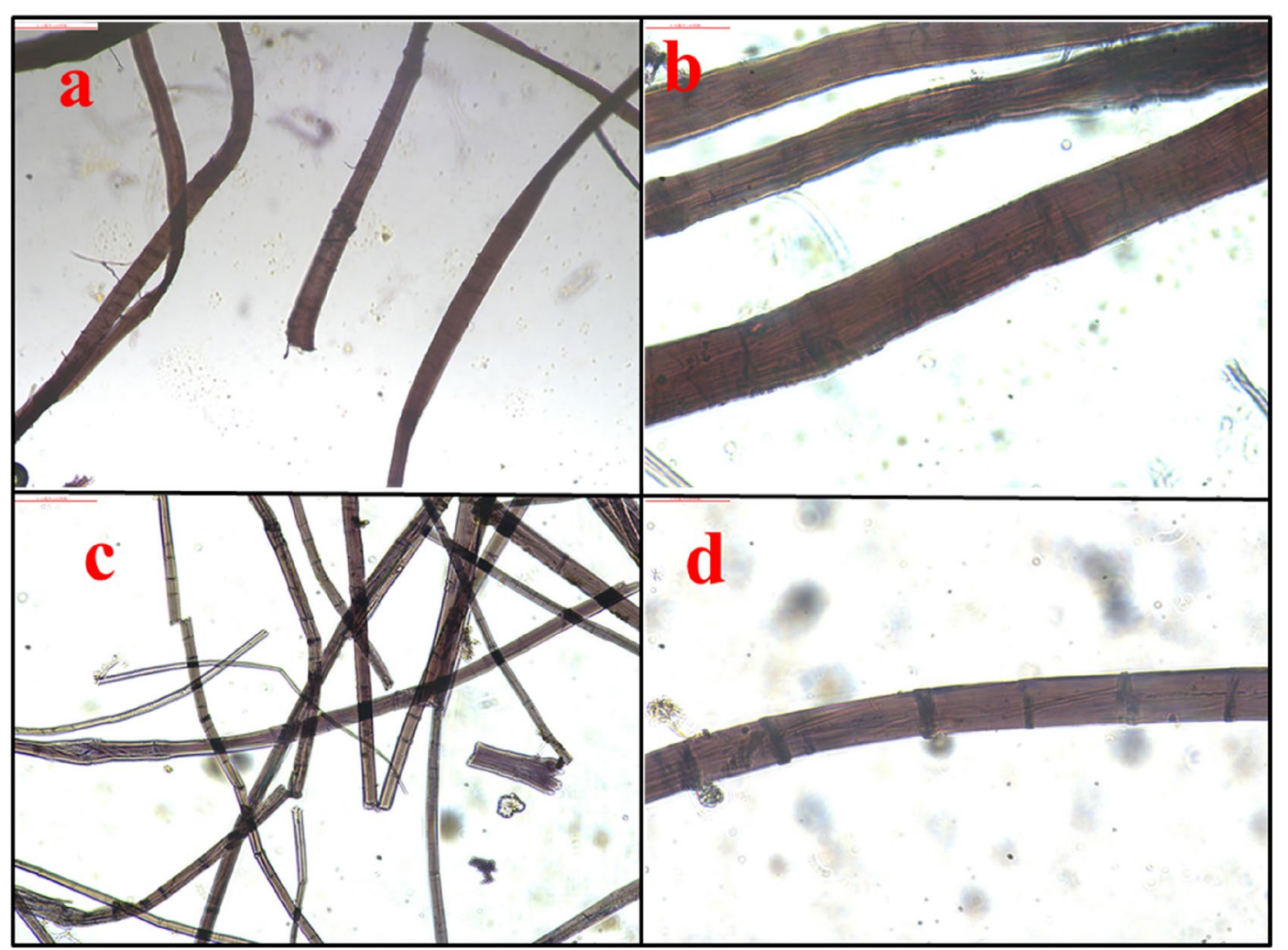

Fig. 3 Fiber analysis of the painted ma textile: fiber morphology of ramie $(\mathbf{a} L M \times 200 ; \mathbf{b} L M \times 400)$, fiber morphology of painted ma textile $(\mathbf{c}$ $L M \times 200 ; \mathbf{d} L M \times 400$ )

sample, showed that the painted ma textile sample displays the same fiber morphology and color with standard ramie fiber. Therefore, it is deduced that the fiber type of ma textile sample is ramie fiber.

\section{Preparation of reinforcement material}

According to the fiber identification result and the principle of compatibility, the reinforcement material was prepared with a ramie net and PVA-217 adhesive.
As shown in Fig. 4a, the ramie thread with a diameter of $0.8-1 \mathrm{~mm}$ was woven as a net with a mesh of $3 \times 3 \mathrm{~mm}$. Figure $4 \mathrm{~b}$ shows that the $5 \%$ concentration of the PVA-217 aqueous solution was prepared as the adhesive, and a spray gun was used to evenly spray the adhesive on the ramie net. The distance between the gun head and the ramie net is $3 \mathrm{~cm}$, the spray pressure of the spray gun is $0.5 \mathrm{MPa} \sim 0.8 \mathrm{MPa}$, and the coating thickness of the adhesive is $15-20 \mu \mathrm{m}$. Finally, the

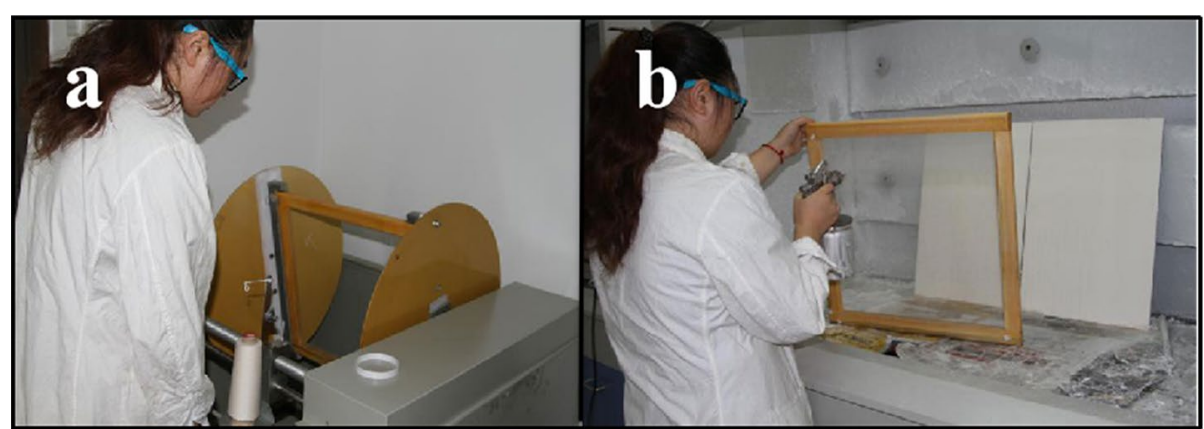

Fig. 4 Preparation of reinforcement net: spin a web on a webbing machine net (a), spray water-soluble adhesive on the woven net (b) 
sprayed ramie net was dried naturally, and cut out of the weaving frame.

\section{Durability evaluations of reinforcement material before and after aging}

Conservation professional groups always employ reinforcement materials with good durability to carry out conservation methods. As the addition to the support fabric will be a permanent intervention to stabilize weakened areas and safely transport the painted ma textile, the durability of the reinforcement material should be evaluated before using it. In this work, the reinforcement materials were evaluated with three kinds of general accelerated aging: dry heat, wet heat, and ultraviolet light. As shown in Table 1, the retention rate of tensile strength of the ramie net after dry heat aging for 5 days and wet heat aging for 5 days is above $80 \%$, and the retention rate of tensile strength after UV light aging for 5 days is above $90 \%$. These aging results show that the ramie net as the reinforcement material possesses good durability for the support and protection of the painted ramie textile. Generally, the durability of the reinforcement material should not be higher than that of the original object, as that would put a strain and cause mechanical stress to the fragile object. Our reinforced ramie net possessed good compatibility with the original object to balance the strain and mechanical stress.

Figure 5 showed that the wet heat aging and ultraviolet light aging had less effect on the color of the reinforcement materials, while the dry heat aging makes more obvious color changes of the PVA film and ramie net. Therefore, it is speculated that the discoloration of the ramie net was caused by the color change of the PVA after aging. The discoloration of the PVA film was caused by the thermal oxidation reaction of the PVA in the dry heat aging box at $105{ }^{\circ} \mathrm{C}$, and some of the hydroxyl groups are oxidized to carbonyl groups, and the reaction mechanism is shown in Fig. 6.

With the increasing aging time, the carbonyl content becomes high, and the color of the PVA film gradually changes from colorless to light yellow, and finally turns to yellow. Meanwhile, the PVA film weakens and becomes brittle and hard. Therefore, it is necessary to further improve the color alterations before and after

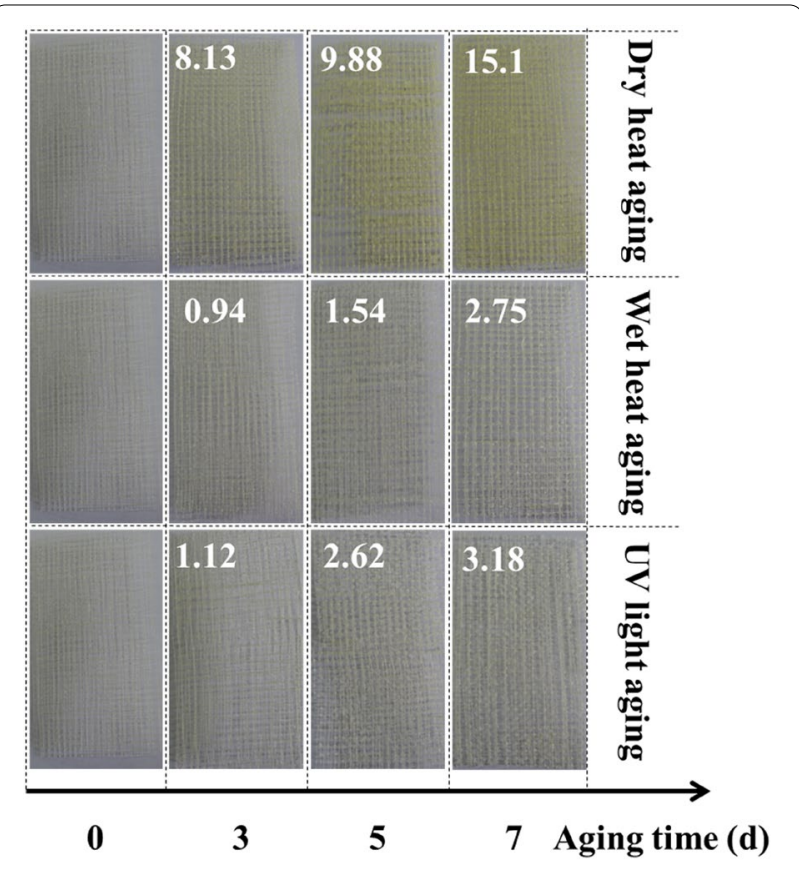

Fig. 5 The color alteration data and effect pictures of several ramie nets with PVA-217 adhesive before and after aging several days by using three aging methods. The chromatic aberration data (white numbers) were listed in the effect pictures

dry heat aging of the reinforcement material, before it can be applied to cultural relics.

\section{Reversibility process}

Retreat-ability is the main concern of conservators nowadays [35]. The water-soluble adhesive has good reversibility as a bonding agent for ramie net and painted ramie textile, and they are very stable bonding (Fig. 7a). The ramie net could be removed from painted ramie textile (Fig. 7b) after spraying an appropriate amount of ultrapure water for a few minutes (Fig. 7c). During the above process, the painted ramie textile sample almost has no damage unless adhesive residues, and it had good reprocessing properties (Fig. 7d).

\section{Conservation process and result}

Through the above scientific evaluation of the reinforcement material, the principles of compatibility,

Table 1 Tensile strength of ramie net before and after 5 days aging

\begin{tabular}{lcrr}
\hline Aging methods & Without aging & Dry heat aging & Wet heat aging \\
\hline Tensile strength $/(\mathrm{kN} / \mathrm{m})$ & 1.30 & 1.05 & 1.08 \\
Retention rate/\% & 100 & 80.67 & 82.52
\end{tabular}




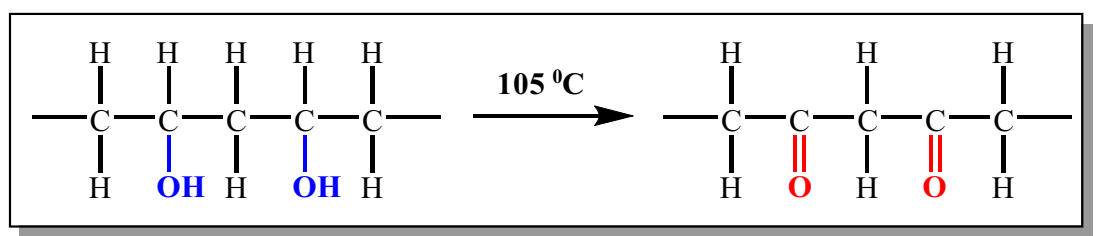

Fig.6 Reaction mechanism of PVA film during heating aging process

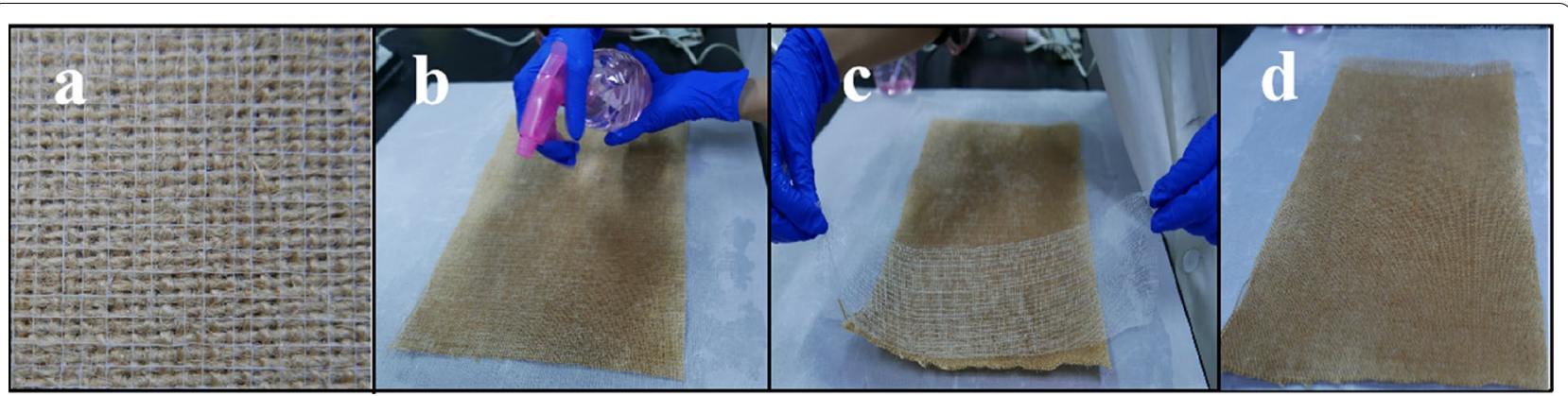

Fig. 7 Reversibility process: before (a) and after (d) removing reinforcement material, spray ultra-pure water (b), removal of reinforcement net (c)

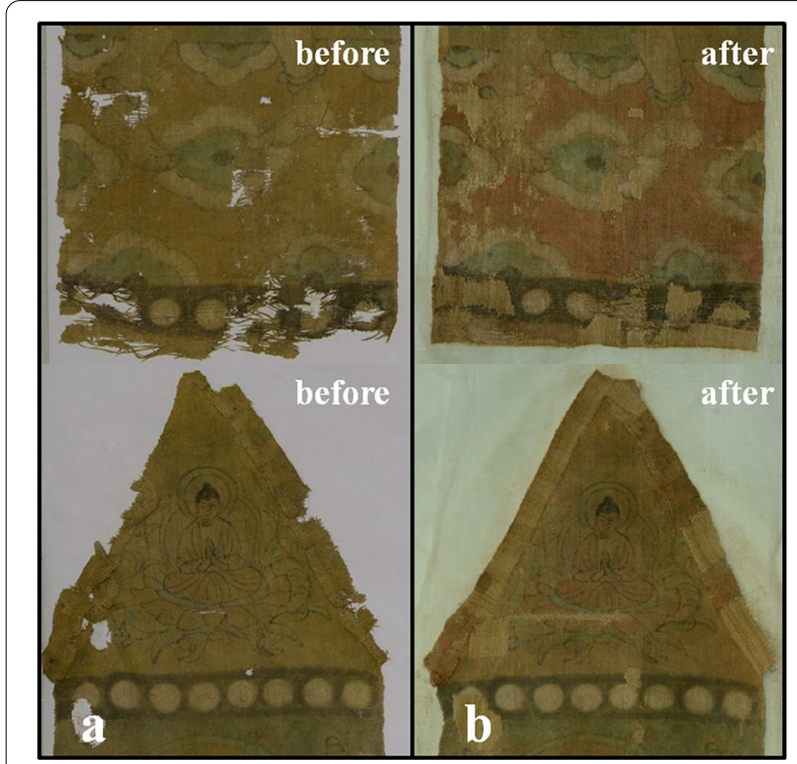

Fig. 8 Effect pictures of decayed ramie fabrics before (a) and after (b) conservation

safety, durability, and reversibility for conservation have been considered. Hence, this reinforcement material was applied to the conservation of the painted textile. As shown in Fig. 8a, this original painted ramie textile was decayed and broken before it was reinforced and restored. In order to preserve the original appearance of the cultural relics, some broken holes, breakages, and breaks were woven and conserved. For safe exhibition and stable preservation of this painted ramie textile, the back of this artwork was strengthened by ramie net, and ramie net was used as the supporting material, stabilizing weakened areas of the painted ramie textile for safe transport. On the other hand, supporting material was also used as a skeleton to stitch the broken parts and helped to fill the missing areas. Overall, the conservation treatment was successful (Fig. 8b). Reinforcement technology of the painted ramie textile in this paper would provide an important reference for the conservation of decayed and extensively damaged textiles. As shown in Figs. 9, 10, $11,12,13,14$ the conservation process showed down as the following:

(1) Realignment of the distorted weave and mechanical cleaning: The painted ramie textile was laid on a table and use tweezers to arrange the damaged fibers on the edge one by one (Fig. 9a). The mechanical cleaning was done by fine and soft wool brush to remove loose dust and dirt (Fig. 9b).

(2) Consolidation of pigment in the colored painting: Because the objects would inevitably get into contact with water during the conservation process, in order to prevent loss of pigment particles, we performed the consolidation with $8 \%$ concentration of aqueous fluorine ethanol and water solution (Fig. 10a). Absorbent cotton swabs were dipped into an appropriate amount of waterbased fluororesin solution, and then it was evenly applied on the colored painting (Fig. 10b), and left to air dry at room temperature. 


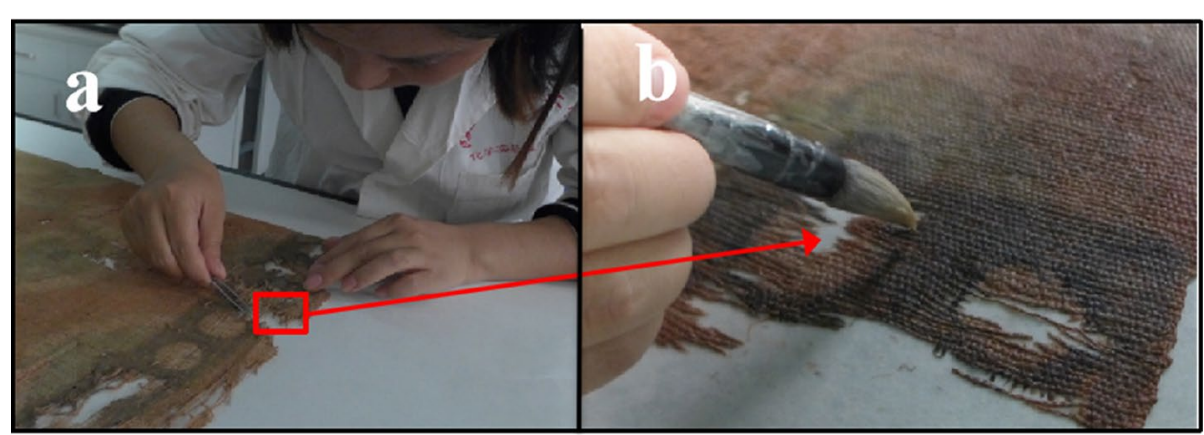

Fig. 9 Using tweezers (a) and soft wool brush (b) to arrange the damaged fibers on the edge one by one

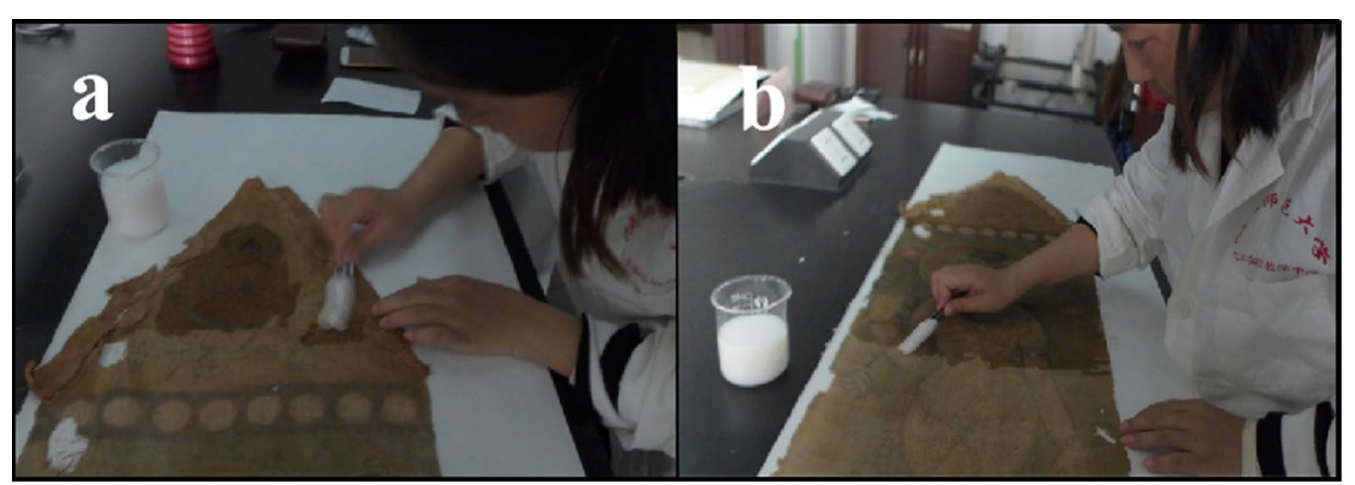

Fig. 10 Consolidation process of pigment in the painted ramie textile

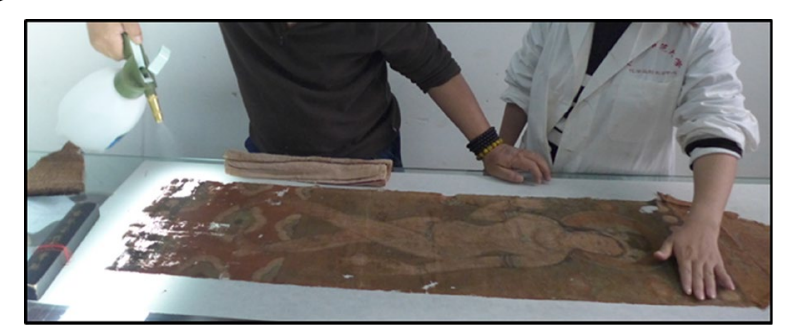

Fig. 11 Wet cleaning and stain removal

(3) Wet cleaning and stain removal: We added ultrapure water into the ultra-fine atomization sprayer, and sprayed slowly on the ramie fabric. With the spray, the ultra-pure water would be flowed out of the backing paper until the liquid flowing out was relatively clean (Fig. 11). Then we rolled it out with a rolled towel to make the objects flat on the tabletop.

(4) Fine realignment on the back of the painted ramie textile: The separated and warped threads were arranged in their original place with fine tweezers
(Fig. 12). Because some of the weft threads were missing, the scattered weft threads were arranged in the original place before the reinforcement procedure.

(5) Reinforcement of the ramie net: We coated the prepared ramie net with PVA-217 adhesive, and attached it to the back of the object and flattened it with a rolled wet towel (Fig. 13a). During this process, PVA-217 adhesive attached to the ramie net would be partly dissolved in water, thereby being sticky enough to adhere and support the object (Fig. 13b), and then left to air dry at room temperature.

(6) In-fill of areas of loss: We used the ramie net as the support where the torn parts were stitched, and the missing areas were woven with aged ramie threads (Fig. 14). Aged ramie was preferred as its mechanical properties would be similar to those of the original object.

\section{Exhibition and collection}

After conservation, the painted ramie textile has been stably exhibited for a long time, which is an important mean to evaluate the conservation materials and treatment. Period of time, the painted ramie textile has 


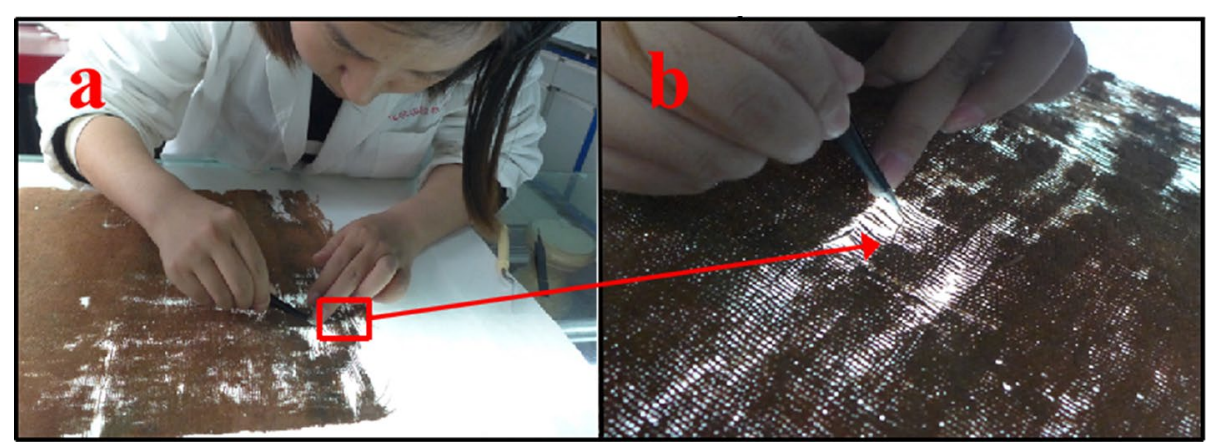

Fig. 12 Fine realignment of the warped threads was based on the original texture of the fabric

been monitored for safety and stability since 2016. The results showed no obvious discoloration, and it has been exhibited in the museum under stable temperature and humidity of $23{ }^{\circ} \mathrm{C}$ and $50 \%$ (Fig. 15), respectively. For the storage, we recommend that it should be unfolded and laid flat if the storage space permits.

\section{Conclusion}

The painted ramie textile reflects the lifestyle and cultural preferences of the people at that time. In this work, a new method was reported for the conservation of ancient colored paintings on ramie textiles. Firstly, the light microscopy observation results showed that the fiber type of the painted ma textile was ramie. Thereby, the ramie net was chosen as the reinforcement

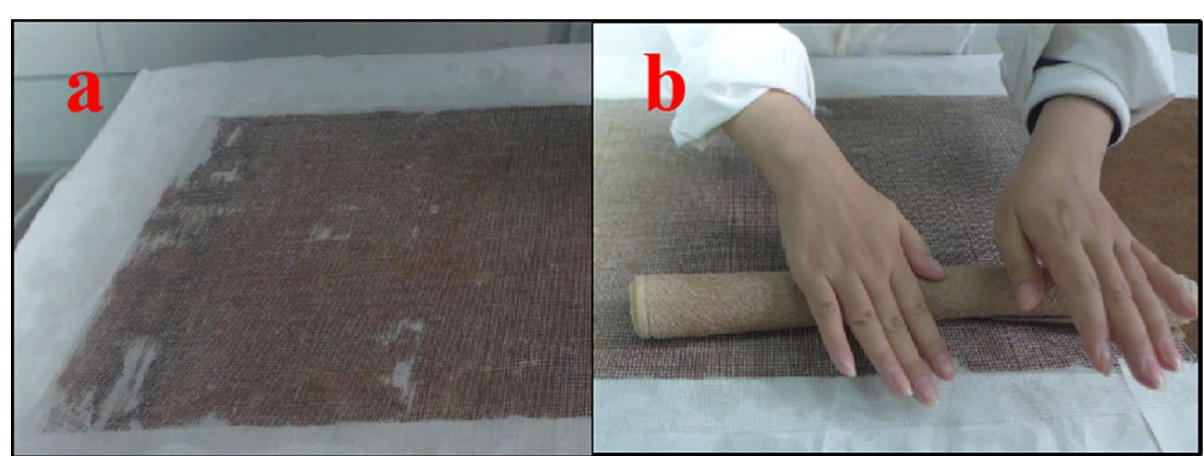

Fig. 13 Reinforcement process of the ramie net: We attached the prepared ramie net to the back of the object (a) and flattened it with a rolled wet towel (b)

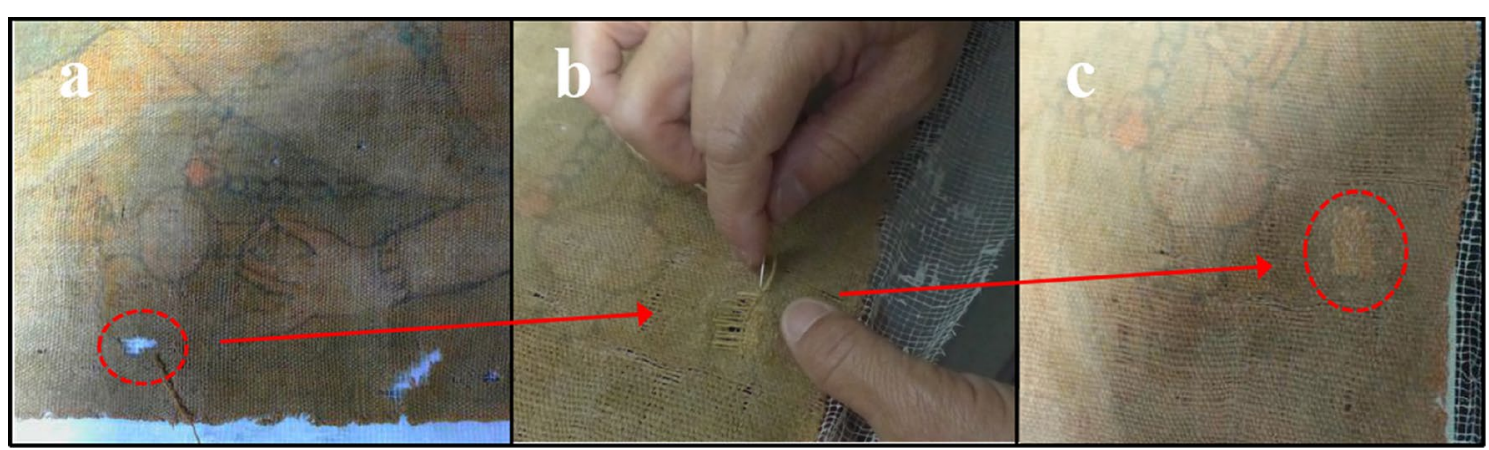

Fig. 14 The weave process of decayed ramie fabrics: before weaving (a), weaving with ramie threads (b), and after weaving (c) 


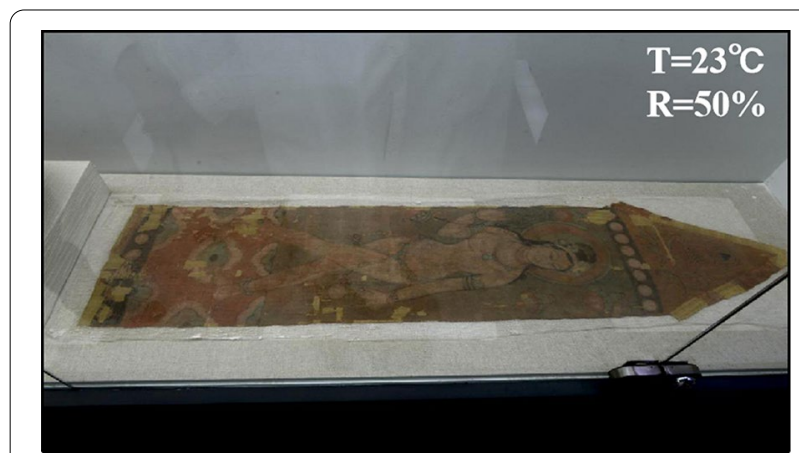

Fig. 15 Exhibition photo of the painted ramie textile in one museum

material with the principles of compatibility. Then, the reinforcement materials were evaluated with three kinds of artificial accelerated aging. The characterized results of the tensile strength and color alteration indicate that the ramie net as the reinforcement material possesses good durability to support and protect the painted ramie textile. For the reversibility, the reinforced ramie net could be removed from the original object, after spraying an appropriate amount of ultrapure water. Finally, the optimal conservation methods were implemented. The use of water-based fluororesin helps to improve the stability of color paint. In-fill of areas of loss could achieve good compatibility with the original object to balance the strain and mechanical stress. After conservation, long-term exhibition has also been shown. Overall, after the identification of the fiber type in the painted ma textile and the performance evaluation of the reinforcement materials, the actual conservation methods have successfully applied to the painted ramie textile during the Liao and Jin Dynasties in China. This work provides an important reference for the fiber identification and conservation of ancient painted ramie textiles.

\section{Abbreviations \\ LM: Light microscopy; RH: Relative humidity.}

\section{Acknowledgements}

The authors would like to thank the conservators and archaeologists in Xi'an Yuanhao Huazang Museum, China for their contributions, and also thank Cong Chen for her help in IR test and Xiaolin Shang for providing guidance on the conservation process.

\section{Authors' contributions}

$J L$ and $Y L$ provided support and guidance for this study. $J$ performed the conservation process of ramie colored drawing and was a major contributor in writing the manuscript. $\mathrm{HX}$ and $\mathrm{DH}$ carried out literature and examination. $\mathrm{XC}$ and JC assisted in sample testing and data analysis. ZJ was involved in the initial concept of the examination. All authors read and approved the final manuscript.

\section{Funding}

The research is financially supported by National Natural Science Foundation of China (51403121), the Key Research and Development Program of Shaanxi Province (2020SF-358, 2017ZDXM-SF-084) and the Fundamental Research Funds for the Central Universities (GK201903054, GK202103056).

\section{Availability of data and materials}

All data are available on request.

\section{Competing interests}

The authors declare that they have no competing interests.

Received: 11 September 2020 Accepted: 18 January 2021 Published online: 31 January 2021

\section{References}

1. Bergfiord C, Mannering U, Frei KM, Gleba M, Scharff AB, Skals I, Heinemeier J, Nosch M-L, Holst B. Nettle as a distinct Bronze Age textile plant. Sci Rep. 2012;2:664/1-664/4

2. Dilillo M, Restivo A, Degano I, Ribechini E, Colombini MP. GC/MS investigations of the total lipid fraction of wool: A new approach for modeling the ageing processes induced by iron-gallic dyestuffs on historical and archaeological textiles. Microchem J. 2015;118:131-40.

3. Brzozowska I, Bogdanowicz A, Szczęsny P, Zielenkiewicz U, Laudy A. Evaluation of bacterial diversity on historical silk velvet textiles from the Museum of King John III's Palace at Wilanów, Poland. Int Biodeter Biodegr. 2018;131:78-87.

4. Kavkler K, Gunde-Cimerman N, Zalar P, Demšar A. FTIR spectroscopy of biodegraded historical textiles. Polym Degrad Stab. 2011;96(4):574-80.

5. Han J, Wanrooij J, Bommel MV, Quye A. Characterisation of chemical components for identifying historical Chinese textile dyes by ultra-high performance liquid chromatography-photodiode array-electrospray ionisation mass spectrometer. J Chromatogr A. 2017;1479:87-96.

6. Pelosi C, Falletta G, Dominicis BD, Baraldi P. The painted silk panels of Palazzo Barberini at Rome The scientific investigation and preservation challenge. Procedia Chem. 2013;8:248-57.

7. Serrano A, Brokerhof A, Ankersmit B, Bommel MV. From the bottom of the sea to the display case: A study into the long-term preservation of archaeological maritime silk textiles in controlled atmosphere. J Cult Herit. 2020;45:91-100.

8. Ahmed HE, Tahoun IF, Elkholy I, Shehata AB, Ziddan Y. Identification of natural dyes in rare Coptic textile using HPLC-DAD and mass spectroscopy in museum of Faculty of Arts Alexandria University, Egypt. Dyes Pigm. 2017;145:486-92.

9. Ford L, Henderson RL, Rayner CM, Blackburn RS. Mild extraction methods using aqueous glucose solution for the analysis of natural dyes in textile artefacts dyed with Dyer's madder (Rubia tinctorum L.). J Chromatogr A. 2017;1487:36-46.

10. Gulmini M, Idone A, Diana E, Gastaldi D, Vaudan D, Aceto M. Identification of dyestuffs in historical textiles: strong and weak points of a non-invasive approach. Dyes Pigm. 2013;98(1):136-45.

11. Shahid M, Wertz J, Degano I, Aceto M, Khan MI, Quye A. Analytical methods for determination of anthraquinone dyes in historical textiles: A review. Anal Chim Acta. 2019;1083:58-87.

12. Kavkler $K$, Demšar $A$. Examination of cellulose textile fibres in historical objects by micro-Raman spectroscopy. Spectrochim Acta A: Mol Biomol Spectrosc. 2011;78(2):740-6.

13. Al-Sharairi N, Sandu ICA, Vasilache V, Sandu I. Recognition of natural silk fibers, dyes and metal threads of historical Romanian textile fragments using the multi-analytical techniques approach. Text Res J. 2020;90(15-16):1671-88.

14. Kavkler K, Gunde-Cimerman N, Zalar P, Demšar A. Fungal contamination of textile objects preserved in Slovene museums and religious institutions. Int Biodeter Biodegr. 2015;97:51-9.

15. Gleba M, Harris S. The first plant bast fibre technology: identifying splicing in archaeological textiles. Archaeol Anthropl Sci. 2019;11(5):2329-46.

16. Tímár-Balázsy Á, Eastop D. Chemical principles of textile conservation. Oxford: Butterworth-Heinemann, Routledge; 1998. 
17. Tolmacheva EG. Preliminary report on conservation and studies of the archaeological textiles from ТТ 23 (season 2018). Египет и сопредельные страны. 2018;2:1-18.

18. Aslanidou D, Tsioptsias C, Panayiotou C. A novel approach for textile cleaning based on supercritical $\mathrm{CO}_{2}$ and Pickering emulsions. J Supercrit Fluids. 2013;76:83-93.

19. Chen $\mathrm{HL}$, Jakes KA, Foreman DW. Preservation of archaeological textiles through fibre mineralization. J Archaeol Sci. 1998;25(10):1015-21.

20. Schön M. The mechanical and supporting effect of stitches in textile conservation. Sweden: University of Gothenburg; 2017.

21. Yang R, Sun J, Xue Z. Production and machining of plant fiber in China. Acad Periodical Farm Products Process. 2009;8:65-9.

22. Olaru A, Malutan T, Ursescu CM, Geba M, Stratulat L. Structural changes in hemp fibers following temperature, humidity and UV or gamma-ray radiation exposure. Cell Chem Technol. 2016;50(1):31-9.

23. Karadag R. Some non-destructive and micro-analytical methods for the conservation on textiles from cultural heritage. Vienna: International Conference on Cultural Heritage and New Technologies; 2014.

24. Bresee RR. General effects of ageing on textiles. J Am Inst Conserv. 1986;25(1):39-48

25. Maria C, Jerzy M. Archaeological textiles-a need for new methods of analysis and reconstruction. Fibres Text East Eur. 2007;15(5-6):64-5.

26. Thompson K, Smith M, Lennard F. A literature review of analytical techniques for materials characterisation of painted textiles-Part 1: categorising painted textiles, sampling and the use of optical tools. J Inst Conserv. 2017:40(1):64-82. https://doi.org/10.1080/19455224.2016.12693 55

27. Cruickshank P, Delaunay H, Harrison L. Painted textiles and canvas paintings: a collaborative approach to lining and mounting. The conservator. 2007;30(1):5-18
28. Abdel-Kareem O, Zidan Y, Lokma N, Ahmed H. Conservation of a rare painted ancient Egyptian textile object from the Egyptian museum in Cairo. E-Preserv Sci J. 2008;5:9-16.

29. Abdel-Kareem O, Alfaisal R. Treatment, conservation and restoration of the Bedouin dyed textiles in the museum of Jordanian heritage. Mediterr Archaeol Archaeom. 2010;10(1):25-36

30. Li JJ. Research on the appearance reinforcement of Buddhism ma color painting in the Liao and Jin Period. Shaanxi: Shaanxi Normal University; 2018.

31. Li T. Technical investigation of ancient Chinese paper based materials with non-destructive chemical methods. Beijing: Graduate University of Chinese Academy of Sciences; 2010.

32. Yang HY, Guo JL, Gong DC. Study on the relationship between morphological characteristics of the fibers of ancient paper and papermaking technologies. China Pulp \& Paper. 2011;30(12):32-5.

33. Zhao XX. Research on identification of hemps in fabric. Prog Text Sci Technol. 2011;03:60-2.

34. Gao L, Wang YP, Wang G, Cheng HT, Tian GL, Gao XS. Methods to identify several natural plant fibers. Shanghai Text Sci Technol. 2009;37(09):7-9.

35. Viñas SM. Contemporary theory of conservation. Oxford: ButterworthHeinemann, Elsevier; 2005.

\section{Publisher's Note}

Springer Nature remains neutral with regard to jurisdictional claims in published maps and institutional affiliations.

\section{Submit your manuscript to a SpringerOpen ${ }^{\circ}$ journal and benefit from:}

- Convenient online submission

- Rigorous peer review

- Open access: articles freely available online

- High visibility within the field

- Retaining the copyright to your article

Submit your next manuscript at $\boldsymbol{\nabla}$ springeropen.com 